\title{
ON THE INFLUENCE ON MURINE LEPROSY OF DDS AND PROMIN
}

The Study on the Chemotherapy of Murine Leprosy (Report III)

\author{
National Leprosarium Kikuchikeifuen (Director M. Miyazaki)
}

Toshio Yoshinaga

DDS prevent tolerably the development of Murine Leprosy.

The effect of DDS upon murine leprosy is almost the same as that of promin, in case of Usmy same dose of free DDS and DDS which is contained in Promin.

\section{DDS 及び PROMIN の鼠癩発症に及ぼす影響}

\section{鼠癩の化学療法に関する研究 第 3 報}

\author{
国立療養所 菊池恵楓園（園長 宮崎松記） \\ 吉 永 敏 夫 \\ （昭和31年 1 月 30 日受稿） \\ （本論文の要旨は昭和 30 年10月20日第 4 回日本瀨学会西部地方会に於て発表した）
}

\begin{abstract}
緒言
戦後治瀨薬として登場したPromin は従来の大風子 油に比し相当顕著な効果を示し, 現在では治瀨薬として 最も主要な地位を占めている。

然るに最近に至つて Promin の原形物質である DDS が注目されつつあるが, そもそも DDS は Promin の構 成分子であり, 叉その Promin の治瀨効果がこの DDS に由来するととが認められている今日では, Promin に 代つて DDS が登場し来るととは至極当然のととである と考えられる。

さて DDS を構造上から考察するに，之は Diaminodiphenylsulfon でめつて, 2 個の Amino-基と 2 個の Phenyl-基を有するサルファ凪であつて, Promin はと の DDS を基本とし之に 2 分子の葡萄糖, 並びに $-\mathrm{SO}_{3} \mathrm{Na}$ 基か結合し構成されたものである。Promin の有効性が この DDS に由来するとせば，この DDS そのものをと り出し之によつて治瀨効果を期待するととが出来るわけ であつて，私は DDS が鼠癩発症に如何なる影響を及ぼ すか，その発症阻止作用如何といら点に主眼を置いて研
\end{abstract}

究を行つた。

DDS を使用して動物実験を試みるに当つて，この D DS が水に対して難溶であるといら事は非常な障碍とな つて打り，経口投与では正確な投与量が望めず，又体内 への吸収など代謝関係からも期待が持でない。然るに最 近吉富製薬から筋注用 DDS 注射夜の提供を得たので之 を用いて本実験に着手した。との DDS 注射夜は特殊の 方法によつて DDS を水溶性としたもので炭つて，その $2 \mathrm{cc}$ 中 $100 \mathrm{mg}$ の DDS を含むものである。

さて次に Promin については従来多くの報告によれば 人稹に対しては周知の通り顕著な治療効果を示すに拘ら ず，鼠攋に対してはあまり効果を認め難いとされてい る。私は DDS の効果を追求する実験を行らに際して, 之と比較するためPromin についても同様な実験を併せ 行い彼我対照して観祭した。そのためにPromin は Protomin 注射夜（吉富製薬）を用い，その中に含まれ ているDDS の分子量を計算し、はじめ私が DDS の鼠 瀨発症に及ぼす影響について実験を行つた際使用した D DS と同量の DDS に相当する Promin 量をとつて鼠 瀨発症に及ぼす影響を観察した。 


\section{実験}

\section{I 実験材料}

(1) DDS，吉富製薬の提供化より筋注用 DDS 注射夜 を使用した。本品は同社工場の研究により特殊の方法に より DDSを水溶液としたもので $2 \mathrm{cc}$ 中 $100 \mathrm{mg}$ を含有 する。私は瀨鼠に筋注を行らに際しては局方注射用蒸溜 水を以て 100 倍乃至 1,000 倍稀彩を行いその $1 \mathrm{cc}$, 即ち DDS 実嗮 0.5 万至 $0.05 \mathrm{mg}$ を 1 回量として使用した。 （実駼方法参照）

(2) Promin, 吉富製菜の Protomin 注射夜を使用し た。その使用量は緒言にても述べた様にその構成分子と して含有されているDDS の量が相等しくなる量をとつ た。即ち Promin の分子量を 988.89，DDS の分子量を 250.31 として計算し，DDS 注射夜 100 倍稀跃液 $1 \mathrm{cc}$ (DDS 実量 $0.5 \mathrm{mg}$ ) に相当するPromin として Protomin 注射液（30\%）を100倍稀秋しその $0.7 \mathrm{cc}$ (Promin 実量 $2.0 \mathrm{mg}$, DDS 実量 $0.5 \mathrm{mg}$ )をとつた。

（3）実験動物 健康白鼠体重 70 乃至 $80 \mathrm{~g}$ の b 90 匹 （動物番号 No. 41-80）を用意し，はじめ約 1 ケ月動 物窒に飼育し懪境汇順心するを待つて之を 4 群伅分ち， 鼠瀨株を接種したが鼠顀株は久留米医大中村教授より分 讓を受けた熊本株 7 代でめつた。常法により肉芽腫を20 倍乳戍としその $1 \mathrm{cc}$ 宛を白鼠左側下䂃部心注射した。

\section{II 実験方法}

鼠液を接種した白鼠40匹を 4 群に分ち各碓10兄を以て 実験を開始した。

第 1 群 DDS 注射群 (DDS $0.5 \mathrm{mg}$ )

第 2 群 DDS 注射群 (DDS $0.05 \mathrm{mg}$ )

第 3 群 Promin 注射群 (DDS $0.5 \mathrm{mg}$ 相当)

第 4 群 対照群

即ち第 1 群代於ては鼠癩接種後約 1 週間を経たる後, 爾 後 1 週間乃至 10 日間の間隔を置き, DDS 0.5mg を 1 回 量として白鼠左側筋内に注射し，との操作を約 4 ケ月間 継続した。

因みに DDS $0.5 \mathrm{mg}$ を人体の場合に換算するに白鼠の 体重を約 $100 \mathrm{~g}$, 人体の重量を約 $50 \mathrm{~kg}$ とすれば人体の場 合 $500 \mathrm{mg}$ 代該当するすのである。

第 2 群は鼠瀨発症に及ぼす薬郕の影響を検するに当り その投与量が岕る程度の影響を与えるべきととを考虑 し, 第 1 群を大量の DDS 投与群と看做し, この第 2 群 をDDS 少量投与群として対照として設けたものであ る。この群には DDS $0.05 \mathrm{mg}$ を注射した。との量は上 記の通り DDS 注射液の稀勫仙は注射用蒸溜水を以て
し，又この量を人体に換算すれば $50 \mathrm{mg}$ に相当するす のである。

第 3 群はPromin を使用して DDS と比較して観察し たもので, Promin の量は実験材料の条にて述べた通り DDS 害嘼を計算しとつたもので，前述の通り $30 \%$ Pro tomin 注射液 100 倍稀瀵液 $0.7 \mathrm{cc}$ をとつた。即ち DDS $0.5 \mathrm{mg}$ に相等し第 1 群の対照でせる。

第 4 群は上記第 1 万至第 3 群の対照実験出つて，DD S, Promin の何れをも使用せず。

かくして本試硔に於ける DDS, 並びに Protomin の 注射回数10回, 実験開始当初より約 4 ケ月を経過し, 鼠 瀨の発症が肉眼的に認められるに至り，剖見し肉眼的所 見と顕微鏡所見とをまとめて実験成績を比較検討した。

\section{III 実験成續}

実験成績は当初鼠瀨を接種し分類した各群各10匹中， 実験中途にして憋死するもの，或桼瀨の発症に甚だし い動摇を示し集約するに妥当を欠くと思われるすのを除 き谷群につき 4 一 6 吃を得た。

このものにつき肉眼的並で顕微鏡的に観察し，その 鼠瀨発症の程度によつてDDS, 並びに Promin のその発 症に及ぼす影響を観察した。

先づ DDS が鼠制登症に及ぼす影響については第 1 表 に示す通りである。

鼠衤の発症程度を知るためには前述の如く肉眼的所見 と顕微鏡的所見に低つたが，そもそもとの鼠瀨発症の程 度を表示するに特定の方法がなく常に研究者の困難を党 えるものでむる。私は先づ肉眼的所見については (1) 体 重を測定し, (2) 局所体表の状態を钼察し, 又 (3) 剖見 して肉芽腫を剝離しその重量を科量した。この表中には この瀨腫の重量を示した。本実験 6 例の平均 $1.3 \mathrm{~g}$ でめ つた。

次に顕微鏡的所見に於ては瀨鼠を剖見し，肉芽腫，淋 巴腺, 及び臟器について淦沫標本をつくり顕微鏡的に鼠

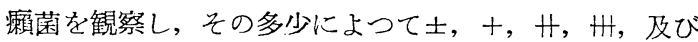
のの 5 段隔に分けて表記した。而して鼠瀨䍜患の程度を 罹患係数を以て示したがこの場合，士=0.5, $\quad+=1$, $H=2, H=3$ と係数をつくり各瀬鼠每に合計して 1 味 の罹患係数を出した。本実験 6 例の罪患係数仕平均 12.8 でめつた。

次に DDS 少量投与群の 実験成績は第 2 表仁示す通り である。 
第I表 DDS（1） $0.5 \mathrm{mg}$ 注射群

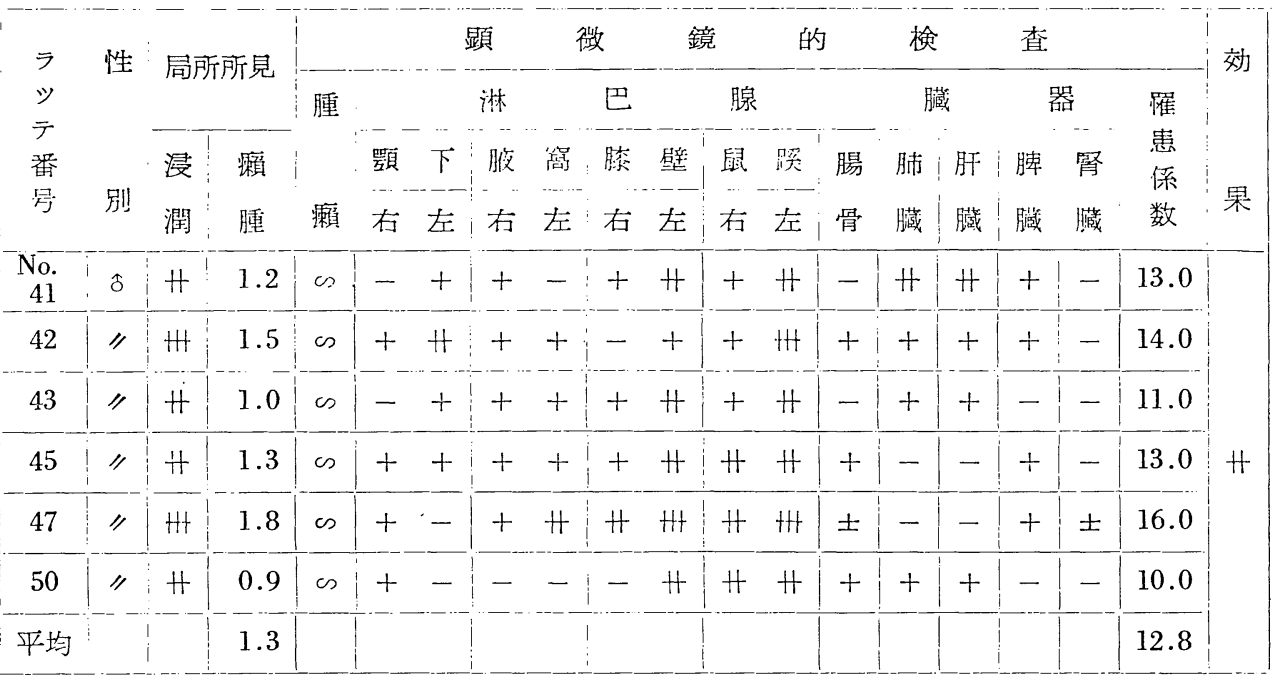

第II表 DDS（2） $0.05 \mathrm{mg}$ 注射群

\begin{tabular}{|c|c|c|c|c|c|c|c|c|c|c|c|c|c|c|c|c|c|}
\hline \multirow{3}{*}{$\begin{array}{l}\text { ラ } \\
\text { ツ } \\
\text { テ } \\
\text { 番 } \\
\text { 号 }\end{array}$} & \multirow[t]{2}{*}{ 性 } & \multicolumn{2}{|c|}{ 局所所見 } & \multirow[t]{2}{*}{ 瀨 } & & & 潹 & \multicolumn{2}{|c|}{ 微 } & \multicolumn{2}{|c|}{ 競 的 } & & 栝 & & $\begin{array}{l}\text { 查 } \\
-\end{array}$ & 合 & \multirow{3}{*}{$\begin{array}{l}\text { 罹 } \\
\text { 患 } \\
\text { 係 } \\
\text { 数 }\end{array}$} \\
\hline & & 浸 & 瓎 & & & 下 & 脽 & 窩 & 膝 & 壁 & 鼠 蹊 & 腸 & 肺 & 肝 & 脾 & 腎 & \\
\hline & & 潤 & 腫 & 腫 & 左 & 左 & 右 & 左 & 右 & 左 & 右 左 & 骨 & 臟 & 葴 & 臟 & 臓 & \\
\hline 71 & $\hat{\delta}$ & H & 1.0 & $\infty$ & + & - & + & - & $H$ & H & H H & - & - & + & + & - & 13.0 \\
\hline 73 & " & $H$ & 1.6 & $\infty$ & + & - & + & + & HH & H & Ht Ht & - & - & + & + & - & 16.0 \\
\hline 75 & " & H & 1.1 & $\infty$ & - & - & + & + & $H$ & H & H H & - & - & \pm & + & - & 11.5 \\
\hline 77 & " & $H$ & 1.6 & $\infty$ & - & - & - & - & + & H & $H H$ & - & - & - & - & - & 13.0 \\
\hline 78 & " & H & 1.3 & $\infty$ & + & - & + & + & $H$ & H & $\mathrm{HH} \mathrm{HH}$ & + & . & \pm & - & - & 14.5 \\
\hline 平均 & & & 1.3 & & & & & & & & & & & & & & 13.6 \\
\hline
\end{tabular}

この表を見るに癩腫の重量 5 例の芦均 $1.3 \mathrm{~g}$ ，䍜患係 数 13.6 でめつて対照（第 4 表，後出）に比較すれ!ボ軽 少の効果を羿めるに過ぎず，又 DDS 多翼使用群たる第 1 表に比較するす䎳か効果が劣る。
次にDDS の対照として行つた Promin の鼠癩発疜に 及添す影響について得た実験成績は第 3 表に示す通りで 岕る。

第III表 PROMIN

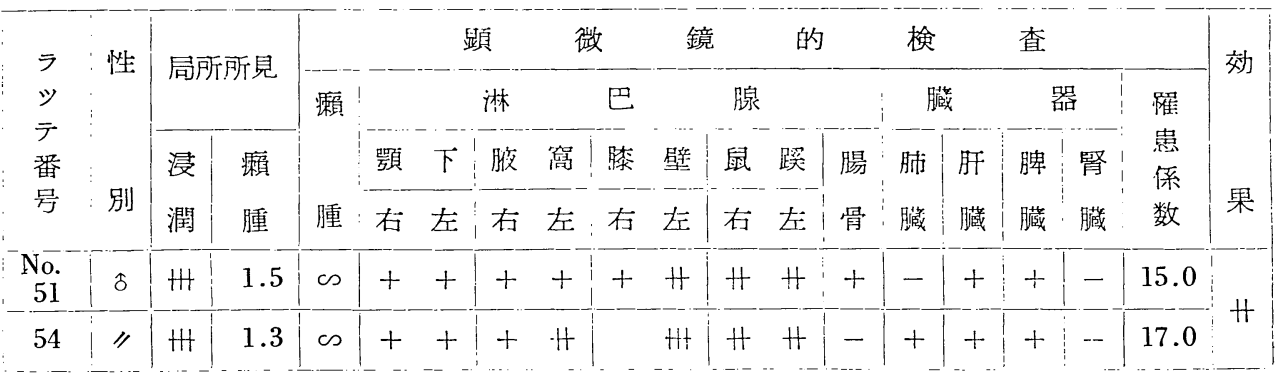




\begin{tabular}{|c|c|c|c|c|c|c|c|c|c|c|c|c|c|c|c|c|c|c|}
\hline 57 & " & $H$ & 0.8 & $\infty$ & - & - & $H$ & $H$ & & - & + & $H$ & - & - & + & + & - & 10.0 \\
\hline 59 & " & $H$ & 1.3 & $\infty$ & - & + & + & + & $H$ & $H$ & $H$ & + & - & - & - & $H$ & - & 12.0 \\
\hline 平均 & & & 1.2 & & & & & & & & & & & & & & & 13.5 \\
\hline
\end{tabular}

Promin の場合は緒言にても述べたる如く鼠瀬に対し てはその治療試験の場合，人㖽に於けるように顕著な効 果は認め難いとされて抢り，又鼠瀨発症抑制訊験に於て も略同様のととがいわれている。私の実験は鼠瀨発症抑 制試験であつて，ての結果も著明な効果を示していな い。が份軽度の効果を示すものである。

又興味める事実はDDS とPromin と比較した場合で
めつて，本実験によつて得た瀨腫の平均重量 $1.2 \mathrm{~g}$ ，崔 患係数 13.5 は DDS の瀨腫平均重量 $1.3 \mathrm{~g}$, 罹患係数 12.8 と大同少異でめつて，との両者が略同程度の鼠䫋 発症抑制作用を示したととである。

終りに第 1 乃至第 3 表に対する対照実験の成績は第 4 表の通りでめつた。

第IV表 対 照 試 験

\begin{tabular}{|c|c|c|c|c|c|c|c|c|c|c|c|c|c|c|c|c|c|c|c|}
\hline \multirow{4}{*}{$\begin{array}{l}\text { ラ } \\
\text { \% } \\
\text { テ } \\
\text { 番 } \\
\text { 号 }\end{array}$} & \multirow{3}{*}{ 性 } & \multirow{2}{*}{\multicolumn{2}{|c|}{ 局所所見 }} & \multicolumn{4}{|c|}{ 顕 } & & 敞 & \multicolumn{2}{|c|}{ 鏡 } & \multicolumn{2}{|c|}{ 的 } & \multicolumn{2}{|c|}{ 検 } & \multicolumn{3}{|l|}{ 查 } & \multirow{4}{*}{ 効 } \\
\hline & & & & \multirow[t]{2}{*}{ 櫴 } & \multicolumn{4}{|c|}{ 淋 } & 巴 & \multicolumn{2}{|r|}{ 脂 } & \multicolumn{2}{|c|}{ 泉 } & \multicolumn{2}{|c|}{ 臓 } & \multicolumn{2}{|c|}{ 器 } & \multirow{3}{*}{$\begin{array}{l}\text { 罹 } \\
\text { 患 } \\
\text { 係 } \\
\text { 数 }\end{array}$} & \\
\hline & & 浸 & 顆 & & & & 腋 & 窩 & 滕 & 壁 & 鼠 & 蹊 & 腸 & 肺 & 肝 & 脾 & 腎 & & \\
\hline & 別 & 潤 & 腫 & 腫 & 右 & 左 & 右 & 左 & 右 & 左 & 右 & 左 & 骨 & 臓 & 臓 & 臓 & 臓 & & \\
\hline $\begin{array}{r}\text { No. } \\
63\end{array}$ & $\hat{o}$ & $H$ & 1.2 & $\infty$ & \pm & + & + & - & + & $H$ & $H$ & $H$ & \pm & - & $H$ & $H$ & - & 14.0 & \\
\hline 65 & " & $H$ & 1.2 & $\infty$ & + & + & H & $H$ & $H$ & Ht & $H$ & $H$ & + & + & $H$ & - & - & 19.0 & \\
\hline 66 & $"$ & H & 1.6 & $\infty$ & + & + & + & + & + & $H$ & $H$ & H & - & - & - & + & - & 13.0 & \\
\hline 67 & " & H & 1.6 & $\infty$ & + & + & + & + & $H$ & $H$ & $H$ & Ht & + & - & - & + & - & 16.0 & - \\
\hline 69 & " & $\mathrm{HH}$ & 1.9 & $\infty$ & + & + & + & H & - & + & $\mathrm{H}$ & $\mathrm{HH}$ & + & + & + & + & - & 18.0 & \\
\hline 70 & " & H & 2.0 & $\infty$ & + & H & + & + & $H$ & $H$ & $H$ & HH & + & - & - & + & - & 17.0 & \\
\hline 平均 & & & 1.6 & & & & & & & & & & & & & & & 16.2 & \\
\hline
\end{tabular}

\section{総括及び考察}

Promin は治牘薬として一応優れた効果を示し，特に 結節瀬に顕著な効果が認められている。DDS は Promin の構成分子でめり，そのPromin の効果が DDS に由来 するととも判つて来た今日, DDS そのものを治癩薬と してとり上げる趨勢にめる事は極めて当然なととであろ ら。然るときはDDS につき治瀨試験, 鼠瀨治療試験, 乃至鼠䫐発症㧕制作用を検討するととは今日緊急の要事 であると思えるので，茲にDDSが鼠瀨発症に及ぼす影響 につきささやかな実験を試みた訳である。Promin は前 述の様に人瀨，特に結節瀬に顕著な効果を現すに反し， 鼠瀨治療試験ではそれ程ですないとされ，又鼠瀨発症阻 止作用についても略同様なととが言われているが，との 事実は人瀨と鼠瀨の相違について考えさせるものを含ん
でいる。

秋に角 DDS が人瀨に使用される前提として幾何かの 参考に資せんとし，私は本研究を行つたが，DDS は鼠 瀨発症に軽度ながら抑制効果を認める事が出来た。

次に DDS と比較する意味でPromin について実験を 行い，との際P romin はその構成分子として含有される DDS の実量が相等しくなるよら計算により割り出した Promin 量をとつて, DDS の場合と同じ条件にて並行 的に実験を企てた。その結果は既にProminについて認 められている如く鼠瀬に対しては大きな効果は認め得な かつたが，佾かつ若干の効果は挙げ得たと思ら。

妶で興味める事実はDDS とPromin とが略同程度の 鼠瀨発症阻止作用を示した事である。

以上の事実から推して DDS も亦Promin と同様に人 瀨への使用が期待出来るものと思われる。 


\section{結 論}

1. DDS は鼠瀨発症に対し軽少ながら抑制作用を示 した。

2. 対照として行つた Promin についても僅少度の効 果を認めた。

3. DDS の鼠瀨発症抑制に対する効果は Promin と 略同程度である。

文献

1）吉永敏夫, 加来天民; レソ゚ラ, 第23巻, 第 2 号,
昭和29年。

2）中村昌弘，新宮正久; レプラ，第20巻，第 4 号， 昭和26年。

3）今枝 保；レプラ，第 23 巻，第 6 号，昭和 29 年。

4）原田禹雄；レプラ，第23巻，第 6 号，昭和 29 年。

5) James A. Doull, M. D. ; International Journal of Leprosy, Vol, 22, No. 4, 1954.

6) John Lowe; Leprosy Review, Vol. XXIII, No. 1 1952 . 